\title{
BANKING SUPERVISION IN INTEGRATED FINANCIAL MARKETS: IMPLICATIONS FOR THE EU
}

\author{
STÉPHANIE STOLZ
}

CESIFO WORKING PAPER NO. 812

CAtegory 6: Monetary Policy AND InTERnAtional Finance

DECEMBER 2002

Presented at CESifo Venice Summer Institute, July 2002

\footnotetext{
An electronic version of the paper may be downloaded

- from the SSRN website: www.SSRN.com

- from the CESifo website: www.CESifo.de
} 


\title{
BANKING SUPERVISION IN INTEGRATED FINANCIAL MARKETS: IMPLICATIONS FOR THE EU
}

\begin{abstract}
I analyze the optimal design of banking supervision in the presence of cross-border lending. Cross-border lending could imply that an individual bank failure in one country could trigger negative spillover effects in another country. Such cross-border contagion effects could turn out to be important in the EU because national banking problems could easily spread via the highly integrated interbank market. I show that if benevolent supervisors are accountable only to their own jurisdiction, they will not take cross-border contagion effects into account. Supervisors with such a national mandate fail to implement the optimum from a supranational perspective. In consequence, the probability of a bank failure will be inefficiently high. Against the background of this result, I argue in favor of institutionalizing an EU "Supervisory Coordination Authority" to which national supervisors are accountable.
\end{abstract}

Keywords: banking supervision, systemic risk, cross-border contagion.

JEL Classification: G21, G28.

Stéphanie Stolz

Kiel Institute for World Economics

Düsternbrooker Weg 120

24105 Kiel

Germany

stephanie.stolz@ifw-kiel.de 


\section{Introduction}

Besides the aim of protecting small depositors, controlling systemic risk is cited as one of the main arguments for banking regulation and supervision. Systemic risk is the probability that the failure of one single bank leads to successive losses along the chain of institutions with negative impact on the whole economy. ${ }^{1}$ The higher the interconnections within the banking system, the higher are the subsequent losses after an individual bank failure. As financial markets have increasingly become integrated across national borders, these losses can partially incur outside the country where the bank failure took place. This contagion effect is particularly relevant in Europe where the highly integrated interbank market could function as a channel for cross-border spillovers.

As banks are not liable to losses incurred by their bankruptcy, they do not account for losses of their direct stakeholders nor the just described negative effects further down the chain when deciding on their investment strategy. In the absence of regulation, the probability of failure is, thus, assumed to be inefficiently high. Hence, regulators employ their instruments in order to increase social welfare. Among the regulatory tools, capital requirements currently seem to be the most accepted instrument. ${ }^{2}$ In order to ensure compliance with the imposed rules, supervisors monitor banks and take countermeasure in case of deviation.

In the EU, it is the "home country" which has full responsibility for banking supervision of individual banks. This national approach means that supervisors are accountable to their own jurisdiction and that their mandate is to guarantee prudential behavior of home banks and to safeguard systemic stability in their own country. Accordingly, incentives are such that supervisors use their discretion to follow national interests. This institutional design has two consequences for the national supervisors' behavior. First, supervisors will pay attention only to the repercussions the failure of a financial institution has on the own economy. However, they will disregard the potential negative effects which are transmitted into other EU countries via the highly integrated interbank market. Second, although supervisors would like to take the risks into account which derive from the bank's activity abroad, they may lack information to do so as their foreign colleagues do not have incentives to deliver the necessary data on the bank's activities abroad.

\footnotetext{
${ }^{1}$ There is no generally accepted definition of systemic risk (see Summer (2002) for a survey). My definition comes closest to Kaufman 's (1995) one (p. 47).

${ }^{2}$ Capital requirements are seen as providing a "buffer" in bad times and preventing banks from risk-taking ex ante. See, for instance, Rochet (1992) and Dewatripont and Tirole (1993).
} 
This incentive or information deficit implies that national authorities try to optimize supervision without taking negative effects on or deriving from other EU countries into consideration. This national approach does not achieve efficient supervision from the perspective of an overall EU optimum as the probability of failure will be inefficiently high. And as increasing integration renders cross-country aspects more important, the current supervisory regime will increasingly deviate from the EU optimum.

In order to adequately align supervisors' incentives, crossborder coordination of supervision has to be implemented. The current devices to arrange bilateral cooperation in practice are Memoranda of Understanding. However, they fail to make supervisors account for foreign externalities as sanctions are missing for the case supervisors do not do so. Thus, I argue in favor of further tightening coordination among national supervisory authorities. Tighter coordination could most effectively be achieved by means of an EU "Supervisory Coordination Authority" to which national supervisors would be accountable. Such an authority would review and evaluate national supervisory procedures. In case of disapproval, adequate sanctions would have to be designed to guarantee compliance which the supranational scheme. In order to minimize political opposition to delegate sovereign rights to the EU, the new committee could be based at a well-established instance with reputation in the field of supervision. Hence, I bring forward the argument that the current mandate of the Banking Supervision Committee, located at the European Central Bank, should be expanded in such a way that it can function as a guiding instance for the national supervisory authorities.

This paper is structured as follows. In section 2, I give details on the institutional design of supervision in the EU. In section 3, building on earlier work by Giammarino, Lewis, and Sappington (1993), I develop an analytical framework to study how a benevolent regulator-supervisor would optimally regulate and monitor a bank which is prone to moral hazard. In section 4 , I deduce the optimal regulatory and supervisory scheme for a closed banking system. In section 5, I show how a nationally optimal regulatory and supervisory regime deviates from the international optimum. In section 6 , I draw conclusions for the optimal supervisory design within the EU. In section 7, I conclude.

\section{Implementation of Supervision in the EU}

In the EU, capital regulation is implemented on a supranational level: The Basel Capital Accord of 1988 has come into effect via the Solvency Ratio (89/647/EEC) and Own Funds (89/299/EEC) directives and is, thus, bind- 
ing for all member states. The new Capital Accord (Basel II) will also be implemented via EU legislation. Like its predecessor, Basel II focuses on the calculation of risk-based capital requirements. Besides, Basel II assigns an important role to supervisors who control the banks' compliance with these rules and take countermeasure in case of deviation. In order to strengthen their powers, the new accord intends to give supervisors more leeway to use instruments they consider appropriate. ${ }^{3}$

In contrast to the supranational approach to regulation, supervision stays with national authorities. ${ }^{4}$ In the EU, this national approach of supervision is implemented by the home country principle which assigns responsibility for overseeing banks to the national authority in the banks' home country. Furthermore, the principle of consolidated supervision requires that the home supervisor is not only liable for a national bank's activities inside the country's borders, but for the control of the whole financial group. However, in practice, banking supervisors in the EU cooperate bilaterally on the basis of so called Memoranda of Understanding (MoUs). These serve to specify the cooperation between supervisors as envisaged in the Second Banking Coordination Directive. MoUs typically include practical provisions with regard to the exchange of information.

As I will argue, this national approach to supervision will not implement an overall EU optimum when an individual bank failure in one country could trigger negative spillover effects in another country. Cross-border establishments and the interbank market are the most probable channels for inter-country contagion. With respect to cross-border establishments, one finds that market shares of foreign banks are extremely high for Ireland and the UK, but remain moderate for most EU countries (see Figure 1). Hence, this channel may gain relevance in the future, but is currently not the most probable one.

In contrast, integration of the interbank market seems rather complete. The largest part of total interbank activity in euro, namely $70 \%$, takes place in the interbank market for unsecured deposits. ${ }^{5}$ The TARGET system is the primary channel for conducting and settling these unsecured interbank transactions in the EU. The TARGET statistics of May 2002 show that the share of cross-border payments in all payments is $21.9 \%$ in volume and 31.1 $\%$ in value. Onother observation is the emergance of a "tiered" interbank

\footnotetext{
${ }^{3}$ The proposal for Basel II states that "supervisors should have the discretion to use the tools best suited to the circumstances of the bank and its operating environment." See Basel Committee on Banking Supervision (2001), p.31.

${ }^{4}$ See the Economic and Financial Committee (2000) for further details on the current EU framework of supervision.

${ }^{5}$ See Santillan, Bayle, and Thygesen (2000).
} 
Figure 1: Market Shares of Foreign Banks in the EU (\%)

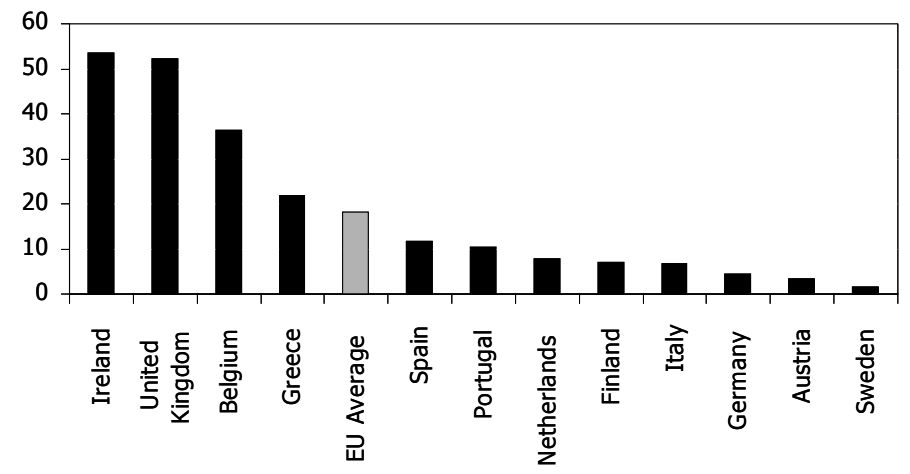

Source: ECB data

Figure 2: Composition of Daily TARGET Transactions

\begin{tabular}{llr} 
Cross-border transfers & $\begin{array}{c}\text { Average Size } \\
\text { of Transaction }\end{array}$ & $\begin{array}{r}\text { Number } \\
\text { of Transactio }\end{array}$ \\
\hline 8.99 Mio. Euro & 53,196 \\
\hline Domestic transfers & 5.59 Mio. Euro & 189,868
\end{tabular}

Source: ECB TARGET Statistics May 2002

market structure: The daily cross-border interbank transfers are on average significantly larger than the domestic ones while the number of transactions is substantially smaller (see Figure 2). This finding is interpreted such that some large banks start to act as "money centre" banks which are active in the whole euro area while smaller banks continue to operate nationally. ${ }^{6}$ As these "money centre" banks form the backbone of the interbank market, financial problems of one of them could easily spread across borders particularly as the interbank market is characterized by large volumes and absence of guarantees. Hence, the interbank market is particularly prone to being a channel for cross-border contagion in the EU.

\footnotetext{
${ }^{6}$ See Enria and Vesala (2002).
} 


\section{Outline of the Model}

While banking regulation and banking supervision are generally regarded as having the same objective, it should be remarked that they are different in that "regulation deals with the formation of rules (... whereas) supervision deals with the enforcement of rules both ex ante (control) and ex post (sanctions)" ${ }^{7}$ According to Basel II, supervisors will have discretion to use tools such as requiring the bank to hold more capital. However, when a supervisor has such wide competencies, he actually acts as a regulator. In this sense, regulation and supervision are often indistinguishable. Hence, regulator and supervisor are modelled as one institution and both expressions are used as synonyms.

The regulator's aim is to maximize social welfare. Banks provide two socially valuable services. First, they take in retail and interbank deposits which are liquid and, thus, valuable to depositors who are assumed to have a preference for liquidity. Second, banks invest these proceeds in risky retail or interbank loans. Limited liability is assumed so that banks are only interested in cash flows which accrue in states other than bankruptcy. This convex pay-off structure encourages banks to increase asset risk, which increases the expected pay-off. Due to this classical moral hazard problem, banks are not interested in employing costly resources in order to lower the risk associated with its loan portfolio. However, such a reduction in portfolio risk would lower the probability of failure and, hence, the probability of losses to depositors and of negative systemic impacts.

The regulator's problem guides my model construction. Many details are borrowed from Giammarino, Lewis, and Sappington (1993) (from now on, referred to as GLS). However, my focus is different: In GLS, the regulator tries to balance the interests of the bank against the interest of the deposit insurance which is funded via distortionary taxes. In contrast, I assume the absence of deposit insurance. Hence, bankruptcy can trigger losses to depositors and systemic costs along the chain of banks which the regulator is concerned to balance against bank profits.

In my model, there are four classes of risk-neutral actors: (1) retail depositors with wealth which can be invested or loaned, (2) companies which seek loans to finance projects, (3) banks that provide intermediation services and are active in the interbank market, and (4) a benevolent regulator-supervisor who maximizes social welfare. More details are provided in the following.

\footnotetext{
${ }^{7}$ See Di Giorgio and Di Noia (2001).
} 


\subsection{Investors/Depositors}

Investors can either invest in illiquid securities (shares of the bank) or liquid assets (deposits). They know that a limited-liablity bank has the incentive to reduce portfolio quality at the expense of depositors (see Jensen and Meckling (1976)). They would anticipate this behavior and demand higher deposit rates. The breakeven return for the bank rises. The bank would, thus, have higher incentive to decrease quality, thereby, increasing the expected pay-off. In the worst case, the market for deposits would break down. The bank could also try to credibly commit itself to a specified quality level in order to lower its deposit rates. However, agency costs would accrue. The existence of a regulator-supervisor simplifies this interaction. He forces the limited-liability bank to take the depositors' losses into account which accrue in case of bankruptcy. Investors are assumed to be indifferent between illiquid equity offering an expected rate of return of $r^{e}$ and liquid deposits. Depositors demand a fixed deposit rate, which I normalize to zero. As in case of bankruptcy, depositors receive less than the amount initially deposited in the bank, the expected rate of return on deposits is less than one. To capture the preference of investors for liquidity most simply, I assume that $r^{e}>1$.

\subsection{Companies}

Companies need funding from the bank to finance their investment projects. I assume that banks are the only source of companies' funding and have all the bargaining power in negotiating financing with the companies. Banks can, thus, capture as profit all the expected surplus from the loans.

\subsection{Banks}

At the start of the model, just prior to $t_{0}$, the bank has one outstanding share and has no outstanding deposits. The bank's only asset is access to a segment of risky loans on the retail and interbank market with an innate quality of $q_{0}$. The objective of the bank is to maximize the value of its initial equity share, its initial wealth. At $t_{0}$, provided it has complied with the rules established by the regulator, the bank can raise funds in the form of outside equity $E$ (a fraction $z$ of the bank's equity) and retail and interbank deposits $D$.

The banks will then invest the proceeds $L=E+D$ in loans to companies. The portfolio size $L$ is given by the market and is, thus, not subject to neither the bank's nor the regulator's decision. The innate quality of the risky projects is $q_{0}$ with $q_{0} \in[\underline{q}, \bar{q}]$ and the average rate of return on all 
loans $L$ of the bank is $r$. The bank is able to raise the quality of its loan portfolio $e$ units above $q_{0}$ if it devotes resources to this purpose with a cost of $C(e)$. I assume that $d C / d e>0$ and $d^{2} C / d e^{2}>0$. The level of quality achieved by the bank is $q=q_{0}+e$. The quality of the loan portfolio has an influence on the distribution of returns $G(r \mid q)$. Higher levels of $q$ will be assumed to shift the distribution of returns in the sense of either firstor second-order stochastic dominance. Analytically, the underlying density function is assumed to have positive support on $[\underline{r}, \bar{r}]$ and:

(FOSD) $G_{q}(r \mid q) \leq 0 \forall r \in[\underline{r}, \bar{r}] \quad$ with strict inequality for some $r$; or

(SOSD) $\int_{r}^{y} G_{q}(r \mid q) d r \leq 0 \forall \in[\underline{r}, \bar{r}] \quad$ with strict inequality for some $y$.

At time $t_{1}$, the cash flows are collected, which consist of the average gross return $r L$ less the cost $\gamma(L)$ of processing $L$ and less the owed payment to depositors $D$. Limited liability of banks is assumed. Hence, deposits $D$ are serviced first. Outside shareholders receive a proportion $z$ of the residual. The rest goes to the owner of the initial share. In case of bankruptcy, the bank is closed and equity holders receive nothing. The whole cash flows go to depositors who have to bear the residual loss.

Given the investment and financing opportunities available to the bank, I define the initial wealth of the bank for a given set of financial decisions as

$$
(1-z) \int_{\underline{r}}^{\bar{r}}(r L-\gamma(L)-D) d G(r \mid q)-C\left(q-q_{0}\right)
$$

with

$$
r^{b}=\frac{D+\gamma(L)}{L}
$$

The bank has to satisfy the following financing constraint

$$
r^{e} E=z \int_{r^{b}}^{\bar{r}}(r L-\gamma(L)-\rho(q) D) d G(r \mid q)
$$

and the cash flow constraint

$$
L=D+E .
$$

Using $E=k L$ with $k$ being the capital-asset ratio, (3), and (4), (1) can be rewritten as

$$
\int_{r^{b}}^{\bar{r}}(r L-\gamma(L)-(1-k) L) d G(r \mid q)-r^{e} k L-C\left(q-q_{0}\right)
$$




\subsection{Regulator/Supervisor}

The regulator aims at limiting the banks's moral hazard due to limited liability. He is assumed to know the functional form of $C(e)$, the relationship between quality and the bank's efforts $\left(q=q_{0}+e\right)$, and the impact of $q$ on $G(r)$. I abstract from information asymmetries. The regulator can, thus, observe the realization of $q_{0}$ and the level of effort $e$.

The regulator uses the capital-asset ratio $k$ and the total realized quality $q$ as regulatory instruments to deal with the bank's moral hazard. He will set both instruments depending on the observed innate quality.

The sequence of actions are described in the following:

Before $t_{0}$ :

- Bank and regulator observe the innate quality of the bank's assets $q_{0}$.

At $t_{0}$ :

- Regulator imposes $\left\{q\left(q_{0}\right), k\left(q_{0}\right)\right\}$ on bank.

- Bank raises equity $E$ and issues deposits $D$ in line with the regulation.

- Bank invests in loans $L$ with the innate quality $q_{0}$ and exerts effort $e$.

- Regulator prevents bank from operating if bank violates regulatory terms.

- If bank abides by regulation, it remains in operation until $t_{1}$.

At $t_{1}$ :

- Cash flows are realized and distributed in the manner described above.

The supervisor is assumed to have a prudential as well as a systemic mandate. Prudential supervision consists of a microeconomic approach that focuses on screening the activity of individual banks with the aim of protecting the assets of banking clients. This last view is the concept predominant in theory and practice (see, for instance, Dewatripont and Tirole's (1994) "representation hypothesis" according to which the regulator-supervisor's task is to protect small and uninformed depositors). Therefore, the supervisor gives negative weight to the loss of depositors in case of bankruptcy.

Systemic supervision is responsible for safeguarding the stability of the entire banking system. Under a systemic supervisory mandate, banking supervisors are concerned about two key issues: first, limiting the risk of financial contagion in the banking system that results from the interconnections 
of banking intermediaries, and secondly, isolating the whole economy from the real impact of systemic instability and failures. Hence, a systemic supervisor assigns negative value to bank failure as bankruptcy triggers costs for the banking system and the whole economy. These costs are supposed to be proportional to the depositors' loss.

The negative value which the prudential and systemic supervisor assigns to bankruptcy is, thus, given by

$$
S\left(q_{0}\right)=(1+b) \int_{\underline{r}}^{r^{b}}\left(r L-\gamma(L)-\left(1-k\left(q_{0}\right)\right) L\right) d G\left(r \mid q\left(q_{0}\right)\right)
$$

with $b>0$ reflecting the triggered costs above the actual loss to depositors. I call $b$ the excess cost factor. The dependence of $k$ and $q$ on the level of innate quality follows from the fact that the bank abides by the regulation.

Apart from the negative value of possible financial distress, the supervisor assigns positive value to the bank's rents $\pi$ :

$$
\begin{aligned}
\pi\left(q_{0}\right)= & \int_{r^{b}}^{\bar{r}}\left[r L-\gamma(L)-\left(1-k\left(q_{0}\right)\right) L\right] \\
& d G\left(r \mid q\left(q_{0}\right)\right)-r^{e} k\left(q_{0}\right) L-C\left(q\left(q_{0}\right)-q_{0}\right) .
\end{aligned}
$$

This expression follows directly from (5) using the fact that the bank's operations must be consistent with the regulatory terms. Recall that these rents reflect the bank's efficiency plus the surplus of the companies' investment projects.

The regulator's problem $[\mathrm{RP}]$ can, thus, be written as:

$$
\max _{q, k} S\left(q_{0}\right)+\pi\left(q_{0}\right)
$$

\section{Optimal Regulation}

The regulator's problem $[\mathrm{RP}]$ can be rewritten as:

$$
\begin{aligned}
\left.\max _{q, k} S\left(q_{0}\right)+\pi\left(q_{0}\right)\right)= & \int_{\underline{r}}^{\bar{r}} \delta\left(r L-\gamma(L)-\left(1-k\left(q_{0}\right)\right) L\right) d G\left(r \mid q\left(q_{0}\right)\right) \\
& -r^{e} k\left(q_{0}\right) L-C\left(q\left(q_{0}\right)-q_{0}\right)
\end{aligned}
$$

where

$$
\delta(x)=\left\{\begin{array}{cc}
{[1+b] x} & \text { for } x \leq 0 \\
x & \text { for } x>0
\end{array}\right.
$$


Then, assuming [FOSD] or [SOSD], at the solution to the regulator's problem, $\forall q_{0} \in[\underline{q}, \bar{q}]:$

$$
\int_{\underline{r}}^{\bar{r}}\left\{\delta\left[r L-\gamma(L)-\left(1-k^{*}\left(q_{0}\right)\right) L\right]\right\} d G_{q}\left(r \mid q^{*}\left(q_{0}\right)\right)-C^{\prime}\left(q^{*}\left(q_{0}\right)-q_{0}\right)=0
$$

and

$$
(1+b) G\left(r^{b *} \mid q^{*}\left(q_{0}\right)\right)+\left(1-G\left(r^{b *} \mid q^{*}\left(q_{0}\right)\right)\right)-r^{e}=0
$$

where $r^{b *} L^{*}-\gamma\left(L^{*}\right)-\rho\left(q^{*}\right)\left(1-k^{*}\right) L^{*}=0$ and asterisks indicate optimal levels. Equations (10) and (11) are obtained by differentiating (9) with respect to $q$ and $k$ respectively. ${ }^{8}$

Equation (10) identifies the first-best level of quality for the bank's loan portfolio. Increases in quality increase the expected cash flows of the bank and reduce the probability of failure. At the optimal level of quality, these marginal gains are equal to the marginal costs of additional quality $C^{\prime}(\cdot)$. The optimal capital structure of the bank is set out in (11) which can be further simplified to

$$
b G\left(r^{b *} \mid q^{*}\left(q_{0}\right)\right)=r^{e}-1 .
$$

The first term in (12) measures the expected savings in bankruptcy cost from increasing the capital-asset ratio. The second term represents the marginal cost of financing an increase in the capital asset ratio. The optimal capitalasset ratio is given where these two quantities are equated. Apart from differences in the costs of equity, debt, and financial distress, the bank's induced capital structure is, hence, similar to that of any other type of firm.

(12) implicitly determines the equilibrium probability of bankruptcy:

$$
G\left(r^{b *} \mid q^{*}\left(q_{0}\right)\right)=\frac{r^{e}-1}{b}
$$

From (13), corollary 1 is obvious:

Corollary 1 Given [FOSD] or [SOSD], the equilibrium probability of bank failure is independent of the level of realized quality.

This may seem surprising as one might expect high-quality banks to experience bankruptcy less often. However, equity is a substitute for quality in reducing bankruptcy (see corollary 4). So, the regulator forces low-quality

\footnotetext{
${ }^{8}$ As I assume that the lowest quality $\underline{q}$ is sufficiently large that it is socially optimal to have all banks to make loans, I can concentrate on interior solutions.
} 
banks to have a higher capital-asset ratio. As the marginal cost of increasing the capital-asset ratio is the same for all banks, the regulator will do so until the bank has the same probability of failure as a high-quality bank.

Corollary 2 Under [FOSD] or [SOSD], the equilibrium probability of bank failure increases with the cost of equity $r^{e}$, i.e.,

$$
\frac{d}{d r^{e}}\left\{G\left(r^{b} \mid q\left(q_{0}\right)\right)\right\}=\frac{1}{b}>0 \quad \forall q_{0} \in[\underline{q}, \bar{q}]
$$

at the solution to $[R P]$.

When the cost of equity rises relative to the cost of debt, it becomes more costly to avoid bankruptcy. Consequently, bankruptcy is permitted to occur with greater frequency in equilibrium.

Corollary 3 Given [FOSD] or [SOSD], the equilibrium probability of bank failure is decreasing with $b$, at the solution to $[R P]$ :

$$
\frac{d}{d b}\left\{G\left(r^{b} \mid q\left(q_{0}\right)\right)\right\}=-\frac{r^{e}-1}{b^{2}}<0 .
$$

As the excess losses from bankruptcy increase, the regulator will optimally ensure a reduced incidence of bankruptcy.

To derive additional results in the case of [SOSD], I assume that the single crossing property (SCP) holds:

(SCP): There exists $\widehat{r} \in(\underline{r}, \bar{r})$ such that $G_{q}(r \mid q) \lesseqgtr 0$ as $r \lesseqgtr \widehat{r}$.

Corollary 4 Suppose [FOSD] holds, or [SOSD] and (SCP) hold with $r^{b}>\widehat{r}$. Then the higher the quality of the bank's portfolio, the lower the required capital-asset ratio, i.e., $d k / d q<0$ at the solution to [RP].

Proof. From equations (2) and (13), $G\left(\frac{(1-k) L+\gamma(L)}{L} \mid q\right)=\frac{r^{e}-1}{b}$. Therefore

$$
\frac{d k}{d q}=\frac{G_{q}(\cdot)}{g(\cdot)}<0
$$




\section{Regulation in a Two-Country Setup}

In the last section, the optimal regulatory scheme was established which a regulator-supervisor would choose if he took the negative impact of bank failure on the banking system and the whole economy into account. Let us think of him as an EU regulator who is able to fully assess the spillover costs independent of where the banking problem first begins and in which country the costs accrue. The regulatory scheme derived in the last section could then be interpreted as the optimal regulation-supervision in the EU as banks would be forced to internalize the whole negative costs which accrue when they fail.

Let us assume a setup with two countries A and B. In every country, there is one bank which represents the national banking system. The terms "bank" and "national banking system" are then synonyms. The two banking systems are assumed to have cross-border linkages via the interbank market. Country A banks deposit in and take deposits from country B banks and vice versa. In each country, there is a regulator-supervisor who controls the national banking system. His national supervisory mandate brings about two differences in regulation compared to the case with only one supranational regulator.

To analytically derive these differences, let us modify the closed-bankingsystem model of the last two sections. In the two-country setup, the level of realized quality of country A's banking system does not longer only depend on innate quality $q_{0, A}$ and effort $e_{A}$, but also on the level of realized quality in country B's banking system $q_{B}$ :

$$
q_{A}=(1-f)\left(q_{0, A}+e_{A}\right)+f q_{B}
$$

where $f$ is the share the home bank invests in the foreign banking system $(0 \leq f \leq 1)$. If the portfolio share of loans to foreign banks is small (low $f)$, the level of realized quality in country B's banking system has only a small impact on realized quality in country A. For the regulator in country A, $q_{0, A}+e_{A}$ and $q_{B}$ are substitutes. Hence, the quality level $q_{A}$ can either be achieved by loans to companies whose quality the bank can enhance by exerting effort $e_{A}$, or by investing in foreign banks with the quality level $q_{B}$ (which adds the more to the bank's quality, the higher the banking systems are integrated).

As discussed above, regulators with a national mandate do not have an incentive to take international spillovers into account. Recall that this incentive contraint is twofold as national supervisors do not take costs into account which accrue abroad (incentive constraint) and they cannot access 
the riskiness of banks' activities abroad due to lacking information (information constraint). In the two-country setup, the incentive constraint means that the country A supervisor does not take excess costs of a national bank breakdown into account which accrue in country B. Hence, the excess cost factor $b_{A}$ in the regulator's objective function reflects only repercussions on the national banking system and the home economy. $b_{A}$ is lower than the excess cost factor in the case of a supranational regulator. With rising integration of the two markets, the national excess cost factor increasingly deviates from the supranational one. According to corollary 3 , the probability of failure would be too high as the bank is not forced to fully internalize the negative effects of bankruptcy. The same holds for country B. Thus, the overall probability of failure is inefficiently high compared to the supranational optimum and is the higher, the more integrated the interbank market is.

Besides, the information deficit means that country A supervisor does not know $q_{B}$ and, thus, is unable to assess the bank's realized quality $q_{A}$. However, incorporating imperfect monitoring is tedious and basically prevents supervisors from fully eliminating bank rents. As all qualitative results continue to hold, I abstain from explicitely modelling this variant and instead refer the interested reader to Lewis and Sappington (1989) who model imperfect monitoring in a related context.

In summary, a supervisory regime where national supervisors lack information on banks' activities abroad and where they do not take international spillovers into account is suboptimal: The induced probability of bank failure is inefficiently high. Hence, a mechanism is to be implemented which aligns the national supervisors' incentives such that $b_{A}$ fully reflects the costs of bank failure independent of where these costs accrue and such that supervisors are forced to appropriately exchange information. Such a mechanism is described in the next section.

However, before moving on to the next section, I analyze the effect of improved information exchange. Using (2) and assuming a mechanism which implements efficient information exchange among supervisor in country A and $\mathrm{B}$, the implicit definition of equilibrium probability of failure (13) becomes

$$
G\left(\frac{\left(1-k^{*}\right) L+\gamma(L)}{L} \mid(1-f)\left(q_{0, A}+e_{A}^{*}\right)+f q_{B}\right)=\frac{r^{e}-1}{b_{A}} .
$$

where $e_{A}^{*}$ is the optimally induced effort of bank A.

As can be seen above, the quality of banking system B can partly substitute for costly effort of banking system A. The same quality level can, 
thus, be realized with lower costs to banking system A. The optimally induced level of realized quality $q_{A}$ increases until the marginal gains are equal to the marginal costs of additional realized quality $q_{A}$ (see first-order condition (10)). A higher quality level corresponds to a lower capital-asset ratio (see Corollary 4). The rise in quality and the drop in the capital-asset ratio increase with the integration of the two banking systems. The same holds true for country B. When country B banks fund country A banks via the interbank market, $q_{A}$ can partly substitute for $e_{B} \cdot q_{B}$ rises and $k_{B}$ falls.

Higher realized quality in country $B$ increases realized quality in A which has a positive repercussion on quality in country B and so forth. This positive interconnection does not lead to a conflict between national supervisors. ${ }^{9}$ However, supervisors use the higher quality level to lower the required capitalasset ratio. Hence, integration leads to a higher realized quality and a lower capital-asset ratio. These two effects compensate for each other so that the probability of failure remains on an inefficiently low level in the two-country setup due to the national supervisors' lacking incentives to internalize foreign spillovers. ${ }^{10}$

To sum up, for a regulatory regime to be efficient, it has to force national supervisors to exchange information on the activity of banks in the host country and to take costs into account which accrue abroad. In this framework, efficient information exchange does not lead to a strategic game in which national supervisors play against eachother, but rather provide the basis for supervisors to implement an efficient regime.

\section{Optimal Supervision in the EU}

The inefficiently low probability of failure in the two-country setup derives from the fact that supervisors do not take foreign spillovers into account which are the result of a national bank's breakdown. This is due to the regulators' incentives set by their national mandates. The same holds for

\footnotetext{
${ }^{9} \mathrm{I}$ abstract here from reputational losses which accrue to supervisors in case of bankruptcy. The reputational losses would accrue as the respective supervisor would obviously not have been successful in preventing bankruptcy. The supervisor would, thus, be reluctant to reveal information on problems of home banks as long as there is the chance that the problems would only be of temporary nature. For a model of conflicts of interest in the supervision of multinational banks in a related context see Holthausen and Roende (2002).

${ }^{10}$ However, if the marginal cost of equity were strictly increasing in equity $E, r^{e}$ would be lower in the two-country setup as the required capital-asset ratio $k$ is lower (see corollary 2 ). Hence, the probability of failure his lower which mitigates the problem due to the supervisors' incentive deficit.
} 
inefficient exchange of information. Hence, the solution consists of changing their incentives such that they consider the negative repercussions abroad.

In practice, EU legislation has eliminated legal barriers to the exchange of information between national supervisory authorities, opening up the opportunity of cooperation. The common device of organizing cooperation on a bilateral basis are voluntary Memoranda of Understanding (MoU), already in place between many national supervisory authorities in the EU (see section 2). However, the network of bilateral MoUs does not properly align supervisors' incentives as they fail to force supervisors to exchange information in a timely and adequate manner. ${ }^{11}$ This is due to their implicit character without a proper sanction mechanism.

As centralization on the EU level does not seem to be politically feasible at the time being, a suitable approach seems to strengthen coordination of national supervisory authorities beyond the existing system of MoUs. ${ }^{12}$ I suggest to implement coordination in the form of a "Supervisory Coordination Authority" on the EU level. ${ }^{13}$ National supervisory authorities would then be accountable to this new institution. ${ }^{14}$ The institution would evaluate the national supervisory process and could intervene when national and international interests come into conflict with each other. For its interventions to be credible and effective, the "Supervisory Coordination Authority" would have the right to levy sanctions against the national supervisory authorities which do not comply with the supranational rules.

However, countries are always hesitant to transfer rights to the supranational level. Hence, in order to find political approval, such a new institution could build on existing EU instances which may have already established a reputation in the field of supervision. The instances which come into question are the Groupe de Contact, the Banking Supervision Committee (BSC), and the Banking Advisory Committee (BAC). The Groupe de Contact is a forum of supervisory experts for the exchange of views on individual institutions and market developments and the assessment of trends in the banking sector. The BSC is based at the European Central Bank. It has a double mandate from the Governing Council, i.e. (1) to assist the European System of Central Banks in contributing to the measures undertaken by the

\footnotetext{
${ }^{11}$ See Enria and Vesala (2002) for further details on the incentive constraints of MoUs.

${ }^{12}$ For arguments regarding a supranational approach to supervision in the EU see Lannoo (2000) and Speyer (2001).

${ }^{13}$ For a related paper see N'Daw (2001), who proposes to institutionalize peer-monitoring among national supervisors in the $\mathrm{EU}$ in order to overcome incentive and information deficits.

${ }^{14}$ For the related discussion on the political accountability of the supervisory authority see Quintyn and Taylor (2002).
} 
competent authorities in the field of prudential supervision of banks and the stability of the financial system, and (2) to provide a multilateral forum for the exchange of information and cooperation between banking supervisors of different member states. The BAC is based at the European Commission and promotes cooperation between the Eurosystem and banking supervisory authorities.

Although there are certainly many strong points in favor of each institution, I argue in favor of the BSC as location of the new "Supervisory Coordination Authority". Firstly, in contrast to the Groupe de Contact, it is based on EU legislation and already reflects a minimum consensus among national banking supervisors. Secondly, although both the BSC and the BAC promote cooperation between the Eurosystem and national supervisors, the BSC additionally deals with market and regulatory developments which are of importance for the EMU banking system. Besides, the BSC's experience with the preparation of national banking legislation argues for its role in the diffusion of sound supervisory practices. ${ }^{15}$

\section{Conclusion}

In this paper, I show how a supervisor should optimally employ risk-adjusted capital-asset ratios to maximize social welfare. The supervisory authority is concerned with the costs of bank failure which accrue in the form of losses to depositors and negative repercussions on other banks and the whole economy. In the integrated EU banking system, a bank breakdown in one country will trigger some of these costs in another country. With a national mandate, supervisors do not take these spillovers into account. From an EU perspective, supervision will not be optimal as the probability of bank failure will be too high throughout Europe.

I argue that the current bilateral cooperation in the form of Memoranda of Understanding is not able to eliminate the supervisory incentive deficit. Further tightening of coordination is needed in order to make supervisors consider international spillovers. I argue in favor of transforming the ECB-based Banking Supervision Committee into a "Supervisory Coordination Authority" to which national supervisors are accountable.

\footnotetext{
${ }^{15}$ I do not argue for or against allocating supervision with the central bank. If the BSC got the supervisory mandate, it could then also be outsourced to an independent institution. See, for instance, Goodhart and Schoenmaker (1993), Goodhart and Schoenmaker (1995), Haubrich (1996), Peek, Rosengren, and Tootell (1999), Goodhart (2000), and Barth et al. (2001) for the debate on whether the monetary policy mandate should be separated from the supervisory mandate. Hawkesby (2001) includes cost-benefit elements and country-specific factors into the discussion.
} 


\section{References}

Barth, J., L. Dopico, D. Nolle, and J. Wilcox (2002). An international comparison and assessment of the structure of bank supervision. Mimeo.

Basel Committee on Banking Supervision (2001). Overview of the new Basel Capital Accord. Consultative document issued for comment by 31 May 2001. Dewatripont, M. and J. Tirole (1993). The prudential regulation of banks. MIT Press.

Di Giorgio, G. and Di Noia (2001). Financial regulation and supervision in the euro area: A four-peak proposal. Wharton Financial Institutions Center Working Paper No. 01-02.

Economic and Financial Committee (2000). Report on financial stability. EU Economic Papers No. 143, May 2000.

Enria, A. and J. Vesala (2002). Externalities in financial supervision: the European case, in: Kremers, J. et al. (ed.), Financial supervision in Europe. Giammarino, R., T. Lewis, and D. Sappington (1993). An incentive approach to banking regulation. Journal of Finance 48 (1993) 1523-1542.

Goodhart, C. (2000). The organisational structure of banking supervision. FSI Occasional Papers no.1, Basel.

Goodhart, C. and D. Schoenmaker (1993). Institutional separation between supervisorys and moetary agencies. Special Paper no. 52, London School of Economics Financial Markets Group.

Goodhart, C. and D. Schoenmaker (1995). Should the functions of monetary policy and banking supervision be separated? Oxford Economic Papers, 47, 539-560.

Haubrich, J. (1996). Combining bank supervision and monetary policy. Economic Commantary, Federal Reserve Bank of Cleveland.

Hawkesby, C. (2001). Central banks and supervisors: The question of insitutional structure and responsibilities. in: L. Halme, C. Hawkesby, J. Healey, I. Saapar, and F. Soussa (ed.), Financial stabiltiy and central bank. Selected Issues for financial safety nets and market discipline. Bank of England Centre for Central Banking Studies, London, 130.

Holthausen, C. and R. Roende (2002). Cooperation in international banking supervision: A political economy approach. Paper presented at the CESifo Venice Summer Insitute 2002.

Jensen, M.C. and W.H. Meckling (1976). Theory of the firm: Managerial behavior, agency costs and ownership structure. Journal of Financial Economics 3 (1976) 305-360. 
Kaufman, G. (1995). Comment on systemic risk, in: Kaufman, G. (ed.), Banking, financial markets, and systemic risk. Research in financial services, private and public policy, vol 7, JAI Press, London, Greenwich, Conneticut. Laffont, J.-J. and J. Tirole (1986). Using cost observation to regulate firms. Journal of Political Economy 94 (1986) 614-641.

Lannoo, K. (2000). Challenges to the structure of financial supervision in the EU. Report of a CEPS Working Party, Brussels.

Lewis, T. and D.Sappington (1989). Procurement with imperfect quality monitoring. Mimeo, University of Florida.

N'Daw, C. (2001). Revisiting the Basel Accord: Supervisory incentive deficit and peer-monitoring arrangements in the EMU. Mimeo.

Peek, J., E. Rosengren, and G. Tootell (1999). Is bank supervision central to central banking? The Quarterly Journal of Economics 114 (2) 629-653.

Quintyn, M. and M. Taylor (2002). Regulatory and supervisory independence and financial stability. IMF Working Paper No. 02/46.

Rochet, J. (1992). Capital requirements and the behavior of commercial banks. European Economic Review 36 (1992) 1137-78.

Santillan, J., M. Bayle, and C. Thygesen (2000). The impact of euro on money and bond markets. European Central Bank Occasional Paper No. 1. Speyer, B. (2001). Internationalisation of banking and banking supervision. Deutsche Bank Research Notes in Economis and Statistics No. 01-7, Frankfurt.

Summer, M. (2002). Banking regulation and systemic risk. Oesterreichische Nationalbank Working Paper No. 57. 


\section{CESifo Working Paper Series}

(for full list see www.cesifo.de)

746 Oleksiy Ivaschenko, Growth and Inequality: Evidence from Transitional Economies, June 2002

747 Burkhard Heer, Should Unemployment Benefits be Related to Previous Earnings?, July 2002

748 Bas van Aarle, Giovanni Di Bartolomeo, Jacob Engwerda, and Joseph Plasmans, Staying Together or Breaking Apart: Policy-makers' Endogenous Coalitions Formation in the European Economic and Monetary Union, July 2002

749 Hans Gersbach, Democratic Mechanisms: Double Majority Rules and Flexible Agenda Costs, July 2002

750 Bruno S. Frey and Stephan Meier, Pro-Social Behavior, Reciprocity or Both?, July 2002

751 Jonas Agell and Helge Bennmarker, Wage Policy and Endogenous Wage Rigidity: A Representative View From the Inside, July 2002

752 Edward Castronova, On Virtual Economies, July 2002

753 Rebecca M. Blank, U.S. Welfare Reform: What's Relevant for Europe?, July 2002

754 Ruslan Lukach and Joseph Plasmans, Measuring Knowledge Spillovers Using Patent Citations: Evidence from the Belgian Firm's Data, July 2002

755 Aaron Tornell and Frank Westermann, Boom-Bust Cycles in Middle Income Countries: Facts and Explanation, July 2002

756 Jan K. Brueckner, Internalization of Airport Congestion: A Network Analysis, July 2002

757 Lawrence M. Kahn, The Impact of Wage-Setting Institutions on the Incidence of Public Employment in the OECD: 1960-98, July 2002

758 Sijbren Cnossen, Tax Policy in the European Union, August 2002

759 Chandima Mendis, External Shocks and Banking Crises in Developing Countries: Does the Exchange Rate Regime Matter?, August 2002

760 Bruno S. Frey and Lars P. Feld, Deterrence and Morale in Taxation: An Empirical Analysis, August 2002

761 Lars Calmfors and Åsa Johansson, Nominal Wage Flexibility, Wage Indexation and Monetary Union, August 2002

762 Alexander R. W. Robson and Stergios Skaperdas, Costly Enforcement of Property Rights and the Coase Theorem, August 2002 
763 Horst Raff, Preferential Trade Agreements and Tax Competition for Foreign Direct Investment, August 2002

764 Alex Cukierman and V. Anton Muscatelli, Do Central Banks have Precautionary Demands for Expansions and for Price Stability? - Theory and Evidence, August 2002

765 Giovanni Peri, Knowledge Flows and Knowledge Externalities, August 2002

766 Daniel Friedman and Nirvikar Singh, Equilibrium Vengeance, August 2002

767 Sam Bucovetsky and Michael Smart, The Efficiency Consequences of Local Revenue Equalization: Tax Competition and Tax Distortions, August 2002

768 Tapio Palokangas, International Labour Market Regulation and Economic Growth with Creative Destruction, August 2002

769 Rudi Dornbusch, The New International Architecture, September 2002

770 Hans-Werner Sinn, Weber's Law and the Biological Evolution of Risk Preferences: The Selective Dominance of the Logarithmic Utility Function, September 2002

771 Thomas Mayer, The Macroeconomic Loss Function: A Critical Note, September 2002

772 Seppo Honkapohja and Kaushik Mitra, Learning Stability in Economies with Heterogenous Agents, September 2002

773 David Laidler, Inflation Targets Versus International Monetary Integration - A Canadian Perspective, September 2002

774 Morten I. Lau, Panu Poutvaara, and Andreas Wagener, The Dynamic Cost of the Draft, September 2002

775 Steven Brakman, Harry Garretsen, and Charles van Marrewijk, Locational Competition and Agglomeration: The Role of Government Spending, September 2002

776 Anke S. Kessler and Christoph Lülfesmann, The Theory of Human Capital Revisited: On the Interaction of General and Specific Investments, September 2002

777 Kjell Erik Lommerud, Frode Meland and Lars Sørgard, Unionized Oligopoly, Trade Liberalization and Location Choice, September 2002

778 Antonio Merlo and François Ortalo-Magné, Bargaining over Residential Real Estate: Evidence from England, September 2002

$779 \mathrm{Yu}-\mathrm{Fu}$ Chen and Michael Funke, Exchange Rate Uncertainty and Labour Market Adjustment under Fixed and Flexible Exchange Rates, September 2002

780 Michael S. Michael, International Migration, Income Taxes and Transfers: A Welfare Analysis, September 2002 
781 Clemens Fuest and Alfons Weichenrieder, Tax Competition and Profit Shifting: On the Relationship between Personal and Corporate Tax Rates, October 2002

782 Jan Bouckaert and Hans Degryse, Softening Competition by Enhancing Entry: An Example from the Banking Industry, October 2002

783 Johann K. Brunner and Susanne Pech, Adverse Selection in the Annuity Market with Sequential and Simultaneous Insurance Demand, October 2002

784 Gregory D. Hess and Eduard Pelz, The Economic Welfare Cost of Conflict: An Empirical Assessment, October 2002

785 Jan Erik Askildsen, Uwe Jirjahn, and Stephen C. Smith, Works Councils and Environmental Investment: Theory and Evidence from German Panel Data, October 2002

786 Geir H. Bjønnes, Dagfinn Rime, and Haakon O. Aa. Solheim, Volume and Volatility in the FX-Market: Does it matter who you are?, October 2002

787 John Evans and John Fingleton, Entry Regulation and the Influence of an Incumbent Special Interest Group, October 2002

788 Wolfgang Ochel, International Comparisons and Transfer of Labour Market Institutions, October 2002

789 B. Gabriela Mundaca, Moral Hazard Effects of Bailing out under Asymmetric Information, October 2002

790 Gene M. Grossman and Edwin L.-C. Lai, International Protection of Intellectual Property, October 2002

791 John Hassler, José V. Rodriguez Mora, Kjetil Storesletten, and Fabrizio Zilibotti, A Positive Theory of Geographic Mobility and Social Insurance, October 2002

792 Paul De Grauwe and Marianna Grimaldi, The Exchange Rate in a Model with Heterogeneous Agents and Transactions Costs, October 2002

793 Guido Friebel and Mariassunta Giannetti, Fighting for Talent: Risk-shifting, Corporate Volatility, and Organizational Change, October 2002

794 Jan Erik Askildsen, Badi H. Baltagi, and Tor Helge Holmås, Will Increased Wages Reduce Shortage of Nurses? A Panel Data Analysis of Nurses' Labour Supply, October 2002

795 Marko Köthenbürger and Panu Poutvaara, Social Security Reform and Intergenerational Trade: Is there Scope for a Pareto-Improvement?, October 2002

796 Paul De Grauwe and Laura Rinaldi, A Model of the Card Payment System and the Interchange Fee, October 2002 
797 Volker Böhm and Tomoo Kikuchi, Dynamics of Endogenous Business Cycles and Exchange Rate Volatility, October 2002

798 Mariam Camarero, Javier Ordóñez, and Cecilio Tamarit, The Euro-Dollar Exchange Rate: Is it Fundamental?, October 2002

799 Misa Tanaka, How Do Bank Capital and Capital Adequacy Regulation Affect the Monetary Transmission Mechanism?, October 2002

800 Jörg Baten and Andrea Wagner, Autarchy, Market Disintegration, and Health: The Mortality and Nutritional Crisis in Nazi Germany, 1933-1937, October 2002

801 Saku Aura, Uncommitted Couples: Some Efficiency and Policy Implications of Marital Bargaining, October 2002

802 Wolfram F. Richter, Delaying Integration of Immigrant Labor for the Purpose of Taxation, October 2002

803 Gil S. Epstein and Shmuel Nitzan, The Politics of Randomness, October 2002

804 John Hassler and José V. Rodriguez Mora, Should UI Benefits Really Fall over Time?, October 2002

805 Friedrich Breyer and Stefan Felder, The Dead-anyway Effect Revis(it)ed, October 2002

806 Assar Lindbeck and Solveig Wikström, E-exchange and the Boundary between Households and Organizations, November 2002

807 Dieter Bös, Contests Among Bureaucrats, November 2002

808 Steven Brakman, Harry Garretsen, and Marc Schramm, The Strategic Bombing of German Cities during World War II and its Impact on City Growth, November 2002

809 Florian Englmaier and Achim Wambach, Contracts and Inequity Aversion, November 2002

810 Sarbajit Sengupta, Delegating Recruitment under Asymmetric Information, December 2002

811 Rajshri Jayaraman, On the Partial Public Provision of a Private Good, December 2002

812 Stéphanie Stolz, Banking Supervision in Integrated Financial Markets: Implications for the EU, December 2002 